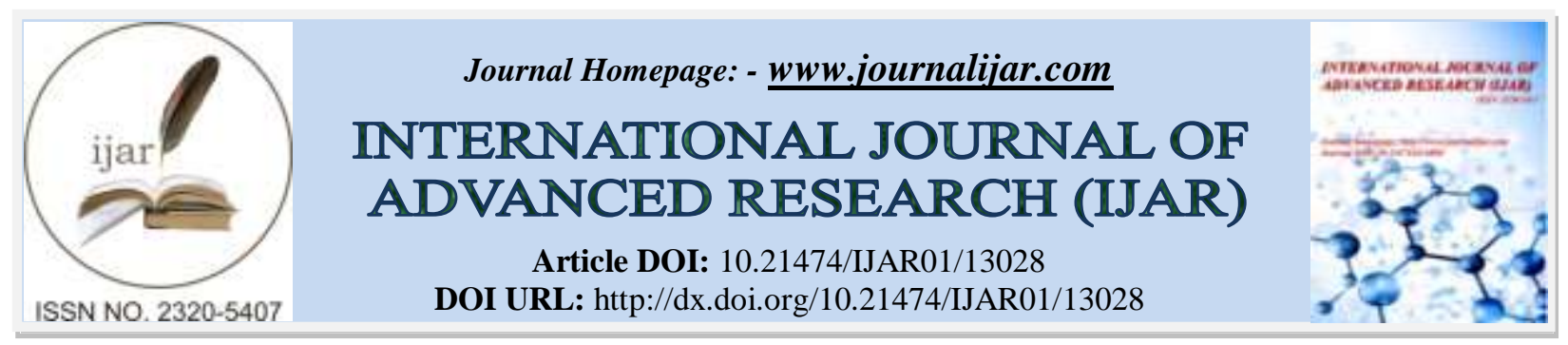

RESEARCH ARTICLE

\title{
ROLE OF MEDICINAL PLANTS IN RURAL SOCIETY OF INDIA
}

\section{Babita}

RNB Global University, Bikaner (Rajasthan) - India.

\section{Manuscript Info}

Manuscript History

Received: 15 April 2021

Final Accepted: 18 May 2021

Published: June 2021

\begin{abstract}
There is a famous saying in Upanishads called "SARVESANTU NIRAMAYA" means may no one suffers from illness. Medical plants can prevent and cure many diseases and also boosts immunity which is very essential in COVID era. Indian farmers are suffering from poverty, debt traps, health and nutritional issues. Rural farmers by growing medical plants can promote health and nutrition status of the entire population as well as their own socio economic and health status. In this paper we have discussed what are medical plants, how they aid rural India, their spillover effects to entire population; problems, solutions, best practices for their cultivation. By tapping the potential of medical plants in rural India, we can make our county ATMANIRBHAR and self-sufficient villages that can realize the dream of Mahatma Gandhi.
\end{abstract}

Copy Right, IJAR, 2021,. All rights reserved.

\section{Introduction:-}

Medicinal plants, also called medicinal herbs. Now a days, herb refer to any part of the plant like fruit, seed, stem, bark, flower, leaf or a root.

Hippocrates is known as the father of modern medicines.

National research center for medicinal \& aromatic plants is situated in Gujarat.According to the WHO, "a medicinal plant is any plant which, in one or more of its organ/parts, contain substances that can be used for therapeutic purposes, or which are precursor for chemo- pharmaceuticals semi synthesis

History of medicinal plants is as long as the history of humans. Early humans, driven by their instinct, taste, and experience, treated their illness by using plants.

India is birth place of various system of medicine such as Ayurveda, Siddha. Herbal medicines have various advantageous over synthetic drug: a) These are chief. B) Easily available

A pivotal role as sources for drug compounds. The wealth of India is natural flora and fauna.

\section{Review}

Herbal medicines proved to be the major remedy in traditional system of medicine. Medical plants may provide three kinds of benefit: health benefit to the people who consume them as medicines; financial benefit to people who 
harvest, process, and distribute them for sale; and society- wide benefit, such as job opportunities, taxation income, and a healthier labor force.

Bioactive compound such as alkaloids, glycosides, steroids, phenols, tannins and other groups of compounds are found in plants. Various plant parts: root, stem, leaves, fruits, seeds, thorn, Gum, whole- plant.

Table:- Medicinal Plants Used in Rural India:

\begin{tabular}{|c|c|c|c|}
\hline SR.NO & SCIENTIFIC NAME & COMMON NAME & MEDICINAL USES \\
\hline 1) & SyzygiumcuminiL. & Jamun & $\begin{array}{l}\text { Seed powder is useful in diarrhea, } \\
\text { dysentery and diabetics }\end{array}$ \\
\hline 2) & $\begin{array}{l}\text { Terminaliaarjuna (Roxb.) } \\
\text { Wight \&Arn. }\end{array}$ & Arjun & $\begin{array}{l}\text { The use of dried Arjun tree bark } \\
\text { powder can prevent heart diseases. } \\
\text { And it reduces cholesterol level. }\end{array}$ \\
\hline 3) & $\begin{array}{l}\text { Tinosporacordifolia (Thunb.) } \\
\text { Miers. }\end{array}$ & Giloy & $\begin{array}{l}\text { The juice of the stem is taken orally as } \\
\text { tonic. }\end{array}$ \\
\hline 4) & Urgineaindica (Roxb.) Kunth & Janglipyaj & $\begin{array}{l}\text { The juice of the bulb is used in } \\
\text { respiratory disorders. }\end{array}$ \\
\hline 5) & Psoraleacorylifolia L. & Babchi & $\begin{array}{l}\text { Use in several diseases like } \\
\text { leukoderma, leprosy. } \\
\text { Roots useful in caries of teeth. } \\
\text { It Promote urination. }\end{array}$ \\
\hline 6) & $\begin{array}{l}\text { Rauvolfiaserpentine } \\
\text { Benth.exKurz }\end{array}$ & Sarpagandha & $\begin{array}{l}\text { Useful in treatment of diabetes. } \\
\text { Used in scurvy. } \\
\text { Used in relaxation of sore throat. }\end{array}$ \\
\hline 7) & Sidacordifolia L. & Bala & $\begin{array}{l}\text { Help for strength. } \\
\text { Useful for asthma. } \\
\text { It is also used for treating blood and } \\
\text { bile disorders. }\end{array}$ \\
\hline 8) & Moringa oleifera Lam. & Sanjana & $\begin{array}{l}\text { Useful in diabetics. } \\
\text { Reduce inflammation. } \\
\text { Lower cholesterol level. }\end{array}$ \\
\hline 9) & Ocimumsanctum L. & Tulsi & $\begin{array}{l}\text { The leaves are used to cure cough and } \\
\text { cold and also to cure boils and ulcers. } \\
\text { The seeds are used as aphrodisiac. }\end{array}$ \\
\hline 10) & Eclipta alba L. & Bhangara & $\begin{array}{l}\text { Liver cleanser } \\
\text { Promote hair growth. } \\
\text { Aids for healthy skin. }\end{array}$ \\
\hline 11) & Phyllanthus emblica Linn. & Amla & Fruits are used in digestion as tonic \\
\hline 12) & $\begin{array}{l}\text { Convolvulus } \quad \text { prostrates } \\
\text { Forssk. }\end{array}$ & Sankhpuspi & $\begin{array}{l}\text { Stimulate digestion. } \\
\text { Prevent headache. } \\
\text { Help in improving memory. }\end{array}$ \\
\hline 13) & Gymnemasylvestre R.Br. & Gurmar & $\begin{array}{l}\text { Reduce sugar level. } \\
\text { Maintain blood pressure. }\end{array}$ \\
\hline 14) & Croton bonplandianusBaill. & Ban tulsi & Seeds oil applied on chest in cold \\
\hline 15) & $\begin{array}{l}\text { Mallotusphilippensis (Lam.) } \\
\text { Muell.Arg. }\end{array}$ & Kamla & $\begin{array}{l}\text { The powder from the exterior of the } \\
\text { fruits is used for roundworms. }\end{array}$ \\
\hline 16) & Curcuma aromaticaSalisb. & Janglihaldi & Protect skin against UV rays. \\
\hline 17) & Curcuma caesiaRoxb. & Kali haldi & $\begin{array}{l}\text { Control weight loss \& regulates blood } \\
\text { sugar. } \\
\text { Reduce cancer. }\end{array}$ \\
\hline 18) & Cuscutareflexa L. & Amarbel & $\begin{array}{l}\text { Used for gastrointestinal problems. } \\
\text { Excellent liver cleanser. } \\
\text { Used for wounds. }\end{array}$ \\
\hline 19) & Datura metal L. & Dhatura & Used in treatment of stomach, asthma, \\
\hline
\end{tabular}




\begin{tabular}{|c|c|c|c|c|}
\hline & & \multirow{2}{*}{\multicolumn{2}{|c|}{ Bramhi }} & \multirow{2}{*}{$\begin{array}{l}\text { bronchitis. } \\
\text { It is used for improving memory. } \\
\text { Reduce inflammation. } \\
\text { Prevent stress. }\end{array}$} \\
\hline 20) & Centellaasiatica (L.) Urban & & & \\
\hline 21) & \multicolumn{2}{|c|}{ ChlorophytumborivilianumSantapur\&R.R.Fern } & Safed Musli & $\begin{array}{l}\text { The roots of the plant are used } \\
\text { for general weakness, as tonic } \\
\text { and aphrodisiac. }\end{array}$ \\
\hline 22) & \multicolumn{2}{|l|}{ Clitoriaternate L. } & Aprajita(Koyla) & $\begin{array}{l}\text { Help in respiratory problems. } \\
\text { Help in avoiding vomit. }\end{array}$ \\
\hline 23) & \multicolumn{2}{|l|}{ CurculigoorchoidesGaertn. } & Kali Musli & $\begin{array}{l}\text { Cure respiratory problems. } \\
\text { Help in liver disorders. }\end{array}$ \\
\hline 24) & \multicolumn{2}{|l|}{ Calotropis procera R.Br. } & Aak & $\begin{array}{l}\text { It helps stabilize blood } \\
\text { circulation. } \\
\text { Protect against skin infection. } \\
\text { It helps treat elephantiasis. }\end{array}$ \\
\hline 25) & \multicolumn{2}{|l|}{ Cassia tora L. } & Chakoda & Help in reducing fever. \\
\hline 26) & \multicolumn{2}{|l|}{$\begin{array}{l}\text { Catharanthusroseus } \\
\text { (L.) G.Don. }\end{array}$} & Sadabahar & $\begin{array}{l}\text { Used in diabetics. } \\
\text { Anti-cancer properties. } \\
\text { Help in treatment of asthma. }\end{array}$ \\
\hline 27) & \multicolumn{2}{|l|}{$\begin{array}{l}\text { Andrographis paniculate } \\
\text { (Burm.F.) Nees }\end{array}$} & Kalmegh & $\begin{array}{l}\text { The plant is used for malarial } \\
\text { fever and as liver tonic. }\end{array}$ \\
\hline 28) & \multicolumn{2}{|l|}{ Annona squamosa L. } & Sitaphal & $\begin{array}{l}\text { Help in digestion. } \\
\text { Prevent stomach ulcer. } \\
\text { Gain body mass. } \\
\text { Good for heart. }\end{array}$ \\
\hline 29) & \multicolumn{2}{|l|}{ Asparagus racemosus Wild. } & Satavar & $\begin{array}{l}\text { The root powder is used to } \\
\text { increase strength and } \\
\text { lactation. }\end{array}$ \\
\hline 30) & \multicolumn{2}{|l|}{ AzadirachtaindicaA.Juss. } & Neem & $\begin{array}{l}\text { Improve immune system. } \\
\text { Help in treating malaria. } \\
\text { Help to protect against } \\
\text { diabetics. }\end{array}$ \\
\hline 31) & \multicolumn{2}{|l|}{ Acacia nilotica $\mathrm{L}$. } & Babul & $\begin{array}{l}\text { Bark is good managing oral } \\
\text { health problems. } \\
\text { Useful in treating diarrohea. }\end{array}$ \\
\hline 32) & \multicolumn{2}{|l|}{ Aloe vera (L.) Burm.F. } & Gwarpatha & $\begin{array}{l}\text { Help in anti- inflammation. } \\
\text { Help in healing wounds. } \\
\text { Treat stretch marks. }\end{array}$ \\
\hline
\end{tabular}

\section{Contribution of Medicinal Plants in Rural India \\ Food security vs nutrition \& hunger:}

Today, India is a net exporter of food grains and produces enough food to feed its population. But, on the other hand faces the triple threat of over-nutrition, under-nutrition and malnutrition across the country. Further, India faces the problem of hunger. India is ranked 94th out of 107countrieson Global Hunger Index, 2020 much behind Bangladesh, Pakistan and Nepal. Medical plants can help to improve health \& nutrition status of rural India.

\section{Enhances Economic Status:}

Agriculture is one of the most employment-intensive sectors. In fact, agriculture in India has been raw material) and service sector (for supporting services) Many raw materials and inputs used in industrial production. Such production linkages demonstrate that a $10 \%$ increase in agricultural output results in an increase in industrial output by as much as 5\%. It is becoming a hub for Entrepreneurship in Agri-based start-ups. 


\section{Social Contribution:}

Agriculture forms the very basis of rural life; penetrating into every aspect of social and cultural life. Status of agriculture has a huge impact on health and status of women and children. For. For example, more than 80 Indian companies have invested about $£ 1.5$ billion.

\section{Community Organizations, Cooperative Societies:}

Encouraging medical plants cultivation can enhance community agriculture \& cooperative societies. This will mitigate the problems of fragmentation of land, mechanization $\&$ modernization of agricultural practices.

\section{Business Opportunities:}

With the change in lifestyle of people, their food habits are more inclined towards herbal \& organic food \&Siddha, Ayurvedic medication. So, there will be huge demand for medical plants in domestic and international market. So, it will attract more avenues for cultivators and can easily double the income of farmers.

\section{Medical Tourism:}

The new emerging form of tourism in India is medical tourism. Promoting rural herbal medical tourism will attract national and international tourists. This will not only increase the revenue of farmers but also other sectors like transport, hospitality etc. This will have spillover effects to the entire society. This will also attract international currency and hence it improves our twin balance sheet problem of the country

\section{Political:}

Agricultural priorities become major part of manifesto of every party. The BJP had set a target of doubling farmers income by 2022 in its manifesto for 2019. The Congress Manifesto,2019 promised to waive the outstanding loan of farmers and ending the non-payment of loans as a criminal offence. Some of the most prominent ones include CHAMPARAN SATYAGRAH, KHEDA PEASANT STRUGGLE etc.

\section{Issues inMedical Plant Cultivation, Suggested Reforms, Best Practices Land and Soil:}

As per World Bank, India has close to $60 \%$ of its land as agricultural land and is the second largest agricultural land globally.

As per latest Agriculture census, close to $67 \%$ of India's farmland is held by the marginal farmers $(<1$ hectare). In addition, only $5 \%$ of Indian farmers control a massive $32 \%$ of land. The organic matter content has been reduced to a critical level of $0.3 \%$ to $0.5 \%$. Subsequently, the conventional problems of soil salinity, soil degradation, desertification and soil erosion have continued to persist.

\section{Landholding Statistics (2010-11)}

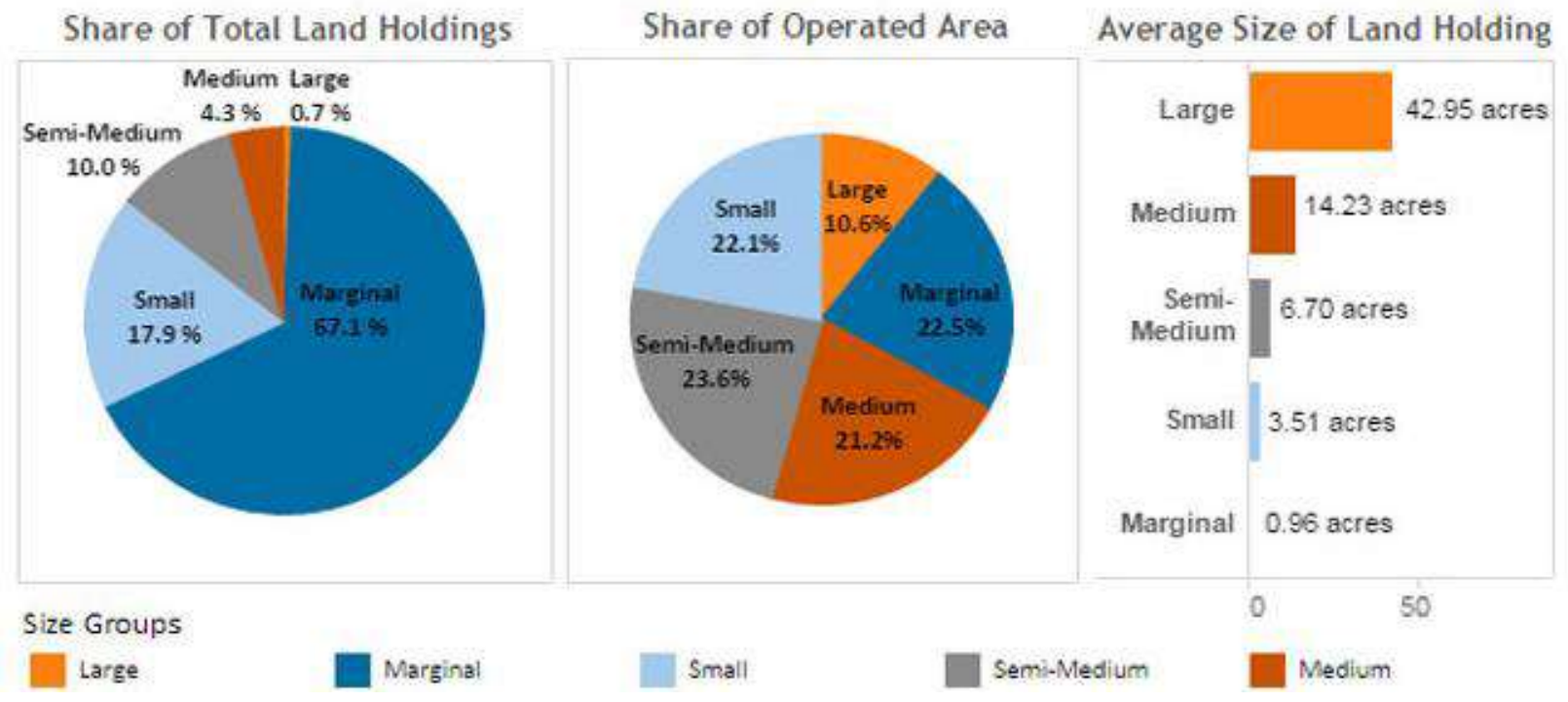




\section{Suggested Reforms:}

There is a need to conclude the agenda land reforms by modernizing and digitizing of land records, distribution of ceiling-surplus and waste lands.

\section{Seeds:}

Seeds play a major input in agriculture with close to $20-25 \%$ productivity dependent on seed quality.

Recently, the emergence of hybrid seeds without due awareness and absence of APRUDENT regulatory framework has adversely impacted the self-sufficiency of farmers.

\section{Suggested Reforms:}

There is a need for reforming the regulatory frame working seeds sector along with encouraging private sector participation in seed production and distribution. There is a need for encouraging community seed and germplasm banks for both conservation and breeding purposes along with a Seed information system.

\section{Irrigation:}

Issues:

Only $46 \%$ of India's net sown area is irrigated and rest continues to depend on monsoons

This problem is aggravated by the huger regional imbalance. Also, Indian agriculture largely depends on ground water with more than $60 \%$ dependence.

\section{Suggested Reforms:}

A mission modern project - Million Wells Recharge PROGRAMME- needs to be initiated targeted at private wells. Finally, there is a need to increase funds for Pradhan Mantri Krishi SINCHAYEE YOJANA(PMKSY) along with establishment of addicted agency at national level to push PMKSY. Also, the PROGRAMME of inter linking of river projects needs to begiven serious consideration.

\section{Agriculture Labor and Mechanization:}

Issues:

Agriculture in India is mostly dominated by manual labor. However, the composition of labor is skewed towards women, lower castes and tribal who have migrated to mainland. In addition, agriculture also suffers from problem of disguised unemployment and labor shortage owing to competition with MNREGA.

In addition, mechanization in agriculture is restricted due to low and fragmented size of land-holdings and inadequate access to credits for buying equipment.

Scientific know-how in agriculture for man important part in agriculture productivity. Also, around $60 \%$ farmers don't receive technical know-how. India farming scenario is also characterized by lack of crop rotation, predominance of cereal-centric and water intensive crops.

\section{Suggested Reforms:}

There is a need to impart agricultural scientific know-how to farmers by reforming KISAN CALL CENTER. Also, imparting agricultural skills to farmers along with participation of self helps groups and Primary Agricultural Cooperative societies (PACS). In addition, there is a need to promote genetically modified (GM)seeds with adequate safeguards. Precision farming and related new technologies like the system of rice intensification, poly house cultivation of fruits and vegetables, laser land levelers, self-propelled sprayers and multi-crop threshers and harvesters.

Finally, there is a need topromote a vibrant,responsive, market oriented and globally competitive agricultural research ecosystem.

\section{Best Practices:}

The participation of private sector under the supervision of public sector in Agricultural Extension participation in Nigeria has been a successful model in agri. Extension services. 'ESAGU' in Andhra Pradesh has been as successful case-study for providing web based personalized AGRO- advisory system Madhya Pradesh has emerged as a role model in AGRI-mechanization by providing for Custom Hiring centers which rents out machinery to small farmers. 


\section{Issue:}

In-spite of series of financial inclusion programs, close to $44 \%$ of rural houses borrow from informal credit sources. Suggested Reforms:

There is a need to expand financial inclusion. There is a need to constitute and Agricultural risk fund. In addition, Women farmers must be issued KISAN CREDIT CARDS and an integrated Credit-cum-Crop-Livestock Human Health insurance package must be launched for farmers.

\section{Reforms - The Unconventional Agenda}

These are recommended by a series of committees and experts, some of the other area worth considering but lesser prioritized are -:

\section{Change of attitude:}

Must be viewed as a sector of infinite opportunities; Shift of attitude from viewing farmers as poor, vulnerable etc.

\section{Integrative approach:}

Need to formulate, implement and monitor policies which adopt a integrative approach to agriculture as apart of rural development - Agriculture, Livestock, Forestry, Water resources etc.

\section{Agri-tourism:}

India has huge potential for Agri-tourism which must become a core element of our Tourism policy.

\section{Urban Farming:}

Agriculture is mostly viewed as a rural practice; Need to change the perception by promoting Urban farming -Truck farming in Semi-Urban areas, Rooftop farming.

\section{Agriculture as Entrepreneurship:}

Next Start-up sector Like IT, Agriculture must be promoted as the new start-up sector in India.

\section{Governance Initiatives:}

A series of steps by government like Agri-Budgeting, Settings up of Agri Innovation Hubs, Constituting an Indian Agriculture Service or Indian rural service.

\section{Cooperative and competitive federalism:}

Agri-Federalism on the lines of fiscal federalism Constitute an empowered committee of State rural development/Agriculture ministers on Agriculture.

\section{Conclusion:-}

The demand for medicinal plant is said to be increasing year after year.

Some major causes of medicinal plant depletion: Increased international demand for medicinal plants, over deforestation, Non- sustainable, destructive, high density harvesting by plant collectors.

So, necessity the conservation of biodiversity by: Raising nurseries, seedling supply, Plantation material,Seed banks, In-vitro method like tissue culture.

It provides Self Employments. It provides high income. It is highly used in Ayurveda, Siddha and Unani system of medicine. Medicinal plants are potential renewable natural resource.

\section{References:-}

1. Pandey, A.K. and Bisaria, A.K. (1997). Rational Utilization of important medicinal plants: A tool for conservation. Indian Forester.124 (4): 197-206.

2. Pandey, A.K. (2000). In Integrated Management of Plant Resources, Ed. Rai, M.K., VermaAjit and Rajak, R.C., Scientific Publishers (India), pp. 68-74.

3. Rai, M.K. and Pandey, A.K. (1997). J. Non-Timber Forest Products, 4(1/2): 61-69.

4. Rai, M.K., Pandey, A.K. and Acharya Deepak. (2000). J.Non-Timber Forest Products, 7(3/4): 237-241 
5. Abelson, P H. 1990. Medicine from plants. Science., 247(4942): 513-514. [Google Scholar]

6.Akhtar, S. 1997. Indigenous technologies of agriculture in Bangladesh, Dhaka, Bangladesh: Bangladesh Academy of Agriculture. [Google Scholar]

7. Schulz V, Hänsel R. Tyler VE. Rational Phytotherapy. A Physician's Guide to Herbal Medicine. 4th ed. Berlin: Springer-Verlag; 2001. p. 306.

8. Calixto JB. Efficacy, safety, quality control, marketing and regulatory guidelines for herbal medicines (phytotherapeutic agents). Braz J Med Biol Res. 2000;33(2):179-89.

9. Bhat KKP. Medicinal plant information databases. Medicinal Plants for Conservation and Health Care, Rome: Food and Agriculture Organization; 1995. 